\title{
Globalization and democracy
}

\section{DEEPAK NAYYAR*}

RESUMO: O impulso da globalização na economia mundial coincidiu com o aumento da democracia política entre os países. A economia tornou-se global, mas a política continua a ser nacional. Este ensaio explora a relação entre globalização e democracia, que não é nem linear e nem caracterizada pela rigidez estrutural. Pretende-se analisar como a globalização pode restringir os graus de liberdade dos Estados-nação e o espaço para a política democrática, e como a democracia política dentro de cada país pode exercer alguns controles e equilíbrios dos mercados e da globalização. $\mathrm{O}$ argumento essencial é que a relação entre globalização e democracia é dialética e não se adapta à caricaturas ideológicas. PALAVRAS-CHAVE: globalização; economia de mercado; democracia política; estado-nação; espaço político; políticas macroeconômicas; economias abertas; trilema; dialética; mídia social.

ABSTRACT: The gathering momentum of globalization in the world economy has coincided with the spread of political democracy across countries. Economies have become global. But politics remains national. This essay explores the relationship between globalization and democracy, which is neither linear nor characterized by structural rigidities. It seeks to analyze how globalization might constrain degrees of freedom for nation states and space for democratic politics, and how political democracy within countries might exercise some checks and balances on markets and globalization. The essential argument is that the relationship between globalization and democracy is dialectical and does not conform to ideological caricatures.

KEYWORDS: globalization; market economy; political democracy; nation state; policy space; macroeconomia policies; open economies; trilemma; dialectical; social media. JEL Classification: O10; O19; O23; F4; FO2; H10; P16.

\footnotetext{
* Emeritus Professor of Economics, School of Social Sciences, Jawaharlal Nehru University, New Delhi. E-mail: nayyar.deepak@gmail.com. This article is based on the author's Golden Jubilee Lecture at the Centre for the Study of Developing Societies, Delhi, on $21^{\text {st }}$ February 2014 and his Plenary Lecture at the Second Celso Furtado Congress on International Development, in Rio de Janeiro, on $20^{\text {th }}$ August 2014. He would like to thank Romila Thapar for comments and suggestions on a preliminary draft. It is also being published in India in the Economic and Political Weekly, 50(19): 39-45. Submetido: 11/março/2014; Aprovado: 17/outubro/2014.
} 


\section{INTRODUCTION}

The gathering momentum of globalization, during the last quarter of the twentieth century and the first decade of the twenty-first century, has coincided with the spread of political democracy across the world. Economies have become global. But politics remains national.

For economists, globalization refers to the expansion of economic transactions and the organization of economic activities across political boundaries of nation states. More precisely, it can be defined as a process associated with increasing economic openness, growing economic interdependence, and deepening economic integration in the world economy. But globalization is a multi-dimensional phenomenon (Nayyar, 2003). Its implications and consequences are not confined to the economy alone but extend to polity and society. There can be little doubt that the whole is different from, if not greater than, the sum total of the parts.

This epoch of globalization has also witnessed the spread of political democracy across countries in the developing world and in the transition economies. Such democratic politics is mostly about electoral democracy in some form, even if people do not always have the political rights or political freedoms that democracies should ensure for their citizens. Nevertheless, it represents a vast change from authoritarian regimes that characterized the developing world until three decades ago. The geographical spread of democracy is striking across Asia, Latin America and Africa. Of course, elections are not always free and fair. And it is not as if authoritarian regimes have vanished. There are many that exist. Some are entrenched, while some are under siege. In a large number of these countries, however, dictatorial regimes are subject to increasing question, as aspirations for democracy are rising everywhere.

In this essay, I explore the relationship between globalization and democracy. It begins with a simple analytical construct derived from economics that suggests tradeoffs between globalization, the nation state and democratic politics. In reality, of course, the relationship is neither linear nor characterized by structural rigidities. It then analyzes the relationship between market economy and political democracy in a national context to show that it is interactive, so that such an approach is useful for an understanding of the international context. It leads into a discussion on how globalization might constrain degrees of freedom for nation states and space for democratic politics. But this provides an incomplete picture because the causation runs in both directions. The essential next step is to consider whether political democracy within countries might exercise some checks and balances on markets and globalization, which also provides a closure. In sum, my argument is that the relationship between globalization and democracy is dialectical and does not conform to ideological caricatures.

\section{ANALYTICAL CONSTRUCT}

It is possible to consider the relationship between the process of globalization in the world economy with political democracy in nation states in terms of a simple 
analytical construct, which is the standard trilemma from open economy macroeconomics. This is, at best, a starting point because it does not quite recognize the complexity, let alone the dialectics of the relationship.

The original trilemma argues that it is not possible for countries to maintain, simultaneously, independent monetary policies, fixed exchange rates and open capital accounts. This open economy trilemma is sometimes described as the "impossible trinity" because it is possible to maintain only two of the three. If an economy chooses capital mobility and fixed exchange rates, it must give up autonomy in monetary policy. If an economy wants fixed exchange rates and autonomy in monetary policy, it must do without capital mobility. If an economy wishes to have autonomy in monetary policy with capital mobility, it cannot have fixed exchange rates.

These possible alternatives are, in fact, observable in the world economy at different points in time. From the late nineteenth century until the Great Depression, the Gold Standard combined fixed exchange rates with capital mobility but countries sacrificed monetary policy autonomy. From the mid-1940s until the early 1970s, the gold exchange standard created at Bretton Woods combined fixed exchange rates with monetary policy autonomy but (more or less) ruled out capital mobility. In the period since the mid-1970s until now, the present era of globalization, most countries sought to combine monetary policy autonomy with capital mobility abandoning fixed exchange rates for a regime of floating exchange rates.

The derived construct first developed by Dani Rodrik (2000) is described as the political trilemma of the world economy. The three nodes of this derivative are globalization, the nation state and democratic politics. In this characterization, globalization describes a substantial integration of national economies into the world economy, the nation state refers to sovereign jurisdiction in terms of laws and institutions, while democratic politics is about electoral democracy, political freedoms and political mobilization. As in the original trilemma, it is possible to sustain only two of the three. If a country wants to stay with the nation state and democratic politics, it cannot sustain deep international economic integration. If a country wants to combine globalization with the nation state, it needs to sacrifice democratic politics. If a country wishes to have democratic politics in a world of globalization, it would have to do without the nation state. This argument is developed further, at much greater length, in Rodrik (2011), where he suggests that countries cannot simultaneously pursue national sovereignty, political democracy, and economic globalization, so that nations can have any two in any combination but not all three.

The underlying reasons are not obvious. The essence of the Rodrik hypothesis is that deeply integrated national economies would conflict with the regulatory and jurisdictional discontinuities created by heterogeneous national laws and institutions, while harmonized laws and institutions that eliminate the significance of national borders conflict with the foundations of democratic politics where governments are accountable to their people. The basic idea is illustrated with a caricature description of reality in the past. The argument runs as follows. From the late 1940s 
to the mid-1970s, the golden age of capitalism, the multilateral economic system made it possible for countries to stay with the nation state and democratic politics by limiting the degree of international economic integration. From the late 1970s until the late 2000s, the age of globalization, which sought to harmonize, policies, institutions and laws across countries, made it possible for countries to combine globalization with the nation state but at the expense of democratic politics. In this construct, it is conceivable to contemplate a future, however unlikely, where it may be possible for countries to combine democratic politics with globalization, by dispensing with the nation state and opting for a world government or global federalism.

The second link in the chain of this storyline is also stressed by Thomas Friedman, from a somewhat different ideological perspective. Of course, his belief in the magic of markets and globalization is not without its limitations and flaws (Chang, 2007), but his characterization of the consequent constraints on governments describes aspects of reality. Friedman uses "Golden Straitjacket" as a phrase to describe how governments everywhere, in this age of globalization, compete with each other to harmonize policies and earn the confidence of international firms and international markets. The following quotation is so explicit that the phrase needs no further explanation: "As your country puts on the Golden Straitjacket, two things tend to happen: your economy grows and your politics shrinks [...] (it) narrows the political and economic policy choices of those in power [...] (so that) it is increasingly difficult to find any real differences between ruling and opposition parties....political choices get reduced to slight nuances [...] to Pepsi and Coke [...] but never to any major deviation from the core golden rules" (Friedman, 1999, p. 87). Yet, the reality is that there has been an expansion of, rather than a contraction in, political democracy during the era that Friedman describes and idolizes.

In my view, this caricature characterization does not capture the complexity of reality. The golden age of capitalism witnessed a rapid liberalization of international trade and international investment to provide the foundations of globalization, even if restrictions on capital mobility meant that it did not extend to international finance. What is more, the age of globalization witnessed a spread, rather than a sacrifice, of democratic politics across countries, even if the rise of political democracy was uneven and incomplete. And this move towards greater democracy in a world of globalization was not attributable to any governance of the world economy in terms of institutions and rules let alone a world government. But that is not all. The major industrialized countries, not only the United States but also countries such as Britain, France, Germany and Japan, are able to combine the nation state and democratic politics with globalization (but for some deference to international financial markets). Surely, this diminishes the explanatory power if not validity of the hypothesis.

Apart from such reality checks, there are two basic problems with the trilemma as an analytical concept. For one, it depicts a caricature world with strong structural rigidities. For another, it creates a binary world with either-or choices. Hence, if there are three possibilities, it is possible to attain only two of the three at a time. 
It is, at best, an analytical abstraction that highlights conflicts or trade offs between three stipulated objectives. And it is not quite appropriate even in the limited context of open economy macroeconomics (Taylor, 2004), where it is simply an analytical construct that highlights conflicts between policy objectives, or instruments, to focus on dilemmas that arise, rather than a depiction of reality.

There is, however, an even more serious problem of transitivity in moving from economics in the original trilemma to politics in the derived trilemma. Each of the three nodes, international economic integration, the nation state, or democratic politics, may represent a range rather than a single unique point, which means that there may be choices within each. Moreover, trade-offs may be a continuum rather than binary choices, which means that it may be possible to have more of two and less of the third. In other words, there could be more choices within and between the three nodes whereas the trilemma only allows choosing two from three. The fundamental problem with such an analytical construct is that it suggests a false precision which is deceptive if not misleading. Of course, in reality, there are conflicts between objectives or desired states. And, wherever there are conflicts, there are bound to be trade-offs. Hence, there are choices to be made. But these should not be reduced to: "pick two, any two".

In this context, there is something to learn from a historical perspective. Globalization in the late twentieth century and early twenty-first century, as much as the earlier era of globalization during the late nineteenth century and early twentieth century, represents neither the end of history nor the end of geography (Nayyar, 2006). It is not the end of history, now as it was not then, because markets and globalization may not be the dominant mode for the world economy in perpetuity. It may have been a world war then and it is the economic crisis now that has created doubts about the wisdom and necessity of deepening economic integration in the world economy. And there was life after globalization then as there will be now. It is not the end of geography, because nation states cannot exist in a vacuum and most must strive to improve the economic conditions of their people to whom governments are accountable.

It is clear that the nation state is a reality that has not withered away. There has been an erosion in its economic space but not in its political space. This reality has been brought home by the global economic crisis (Nayyar, 2011). At the same time, democratic politics is an aspiration that is on the rise everywhere. The spread of political democracy has coincided in time with the advent of market economy. There are fewer authoritarian regimes and more democratic regimes. In sum, the nation state is a reality embedded in history that has emerged stronger from the global economic crisis. Democratic politics, which has gathered both momentum and strength in the recent past, is increasingly a prior, as there is a rights consciousness among citizens. In contrast, the degree of international economic integration is a matter of strategic choice in terms of speed, sequence and engagement. It depends on choices made by the nation state where, ultimately, governments can decide only in accordance with preferences of people. And if it produces unequal outcomes, globalization is unsustainable in terms of both economics and politics. 


\section{MARKETS AND DEMOCRACY}

The nature of the relationship between market economy and political democracy in the national context is perhaps the more appropriate starting point for an understanding of the relationship between globalization and democracy situated in the international context. The causation is interactive as it runs in both directions and the relationship is dialectical as one shapes the other.

The essence of the tension between the economics of markets and the politics of democracy must be recognized. In a market economy, people vote with their money in the market place. The underlying principle is one-dollar-one-vote. But a political democracy works on the basis of one-person-one-vote (Bhaduri and Nayyar, 1996). The distribution of votes, unlike the distribution of incomes or assets, is equal. One adult has one vote in politics, even though a rich person has more votes than a poor person, in terms of purchasing power, in the market. This tension may be compounded by a related asymmetry between economy and polity. The people who are excluded by the economics of markets are included by the politics of democracy. Hence, exclusion and inclusion are asymmetrical in economics and politics. The distribution of capabilities is also uneven in the economic and political spheres. The rich dominate a market economy in terms of purchasing power. But the poor have a strong voice in a political democracy in terms of votes. And there is a mismatch.

It is clear that, in reconciling market economy and political democracy, a sensible compromise must be reached between the economic directions that the market sets on the basis of purchasing power and the priorities that a political system sets on the basis of one-person-one-vote. In this context, it is not surprising that successive generations of economic thinkers and social philosophers have stressed the role of the State in this process of mediation. The reason is important even if it is not obvious. Governments are accountable to their people, whereas markets are not. In a democracy, of course, governments are elected by the people. But even where they are not, the state needs legitimization from the people, most of whom are not rich or are poor. The task of reconciliation and mediation is obviously difficult but clearly necessary (Nayyar, 2003a).

Markets are responsive to the demands of rich people and not to the needs of the poor people. This is inherent in the logic of markets where decisions about what is produced are based on demand and not on need. Thus, markets produce goods for which there is enough purchasing power. The output-mix depends upon the composition of expenditure and the size of the market. Since the rich have more purchasing power, markets, left to themselves, are likely to produce more soft drinks and not safer drinking water. In this manner, markets include people with entitlements but exclude people without entitlements. In theory, every economic agent has the freedom to choose. In practice, there is a choice for some but not for others. And there is more choice for some than for others.

Democracies are more responsive to people with a voice than to people at large. People without a political voice are often simply neglected. There are, of course, 
problems associated with majority rule which might lead some democracies to exclude minorities. Even if we abstract from such problems, however, the principle of one-person-one-vote does not make every citizen equal in a political democracy. For, in the real world, social and economic inequalities are inevitably reflected in the political process. In theory, democracy provides every citizen political freedom in the form of civil rights and political liberties. In practice, there is freedom for some but not for others. And there is more freedom for some than for others.

It is only to be expected that there is an interaction between exclusion from the market in the economic sphere and exclusion from democracy in the political sphere. An economic exclusion from livelihood often creates or accentuates a political exclusion from rights. Thus, for the poor in a democracy the right to vote may exist in principle, but in practice it may be taken away by coercion or coaxed away by material incentives at the time of elections. Similarly, the very poor are vulnerable to exploitation or oppression because their civil rights or equality before the law exists in principle but are difficult to protect or preserve in practice. The reason is simple. They do not have the resources to claim or the power to assert their rights.

Exclusion extends beyond the economic and the political to the social and cultural spheres. The social manifestations of exclusion can be powerful. At the same time, economic exclusion accentuates social exclusion, while social exclusion accentuates political exclusion. Similarly, cultural exclusion such as that of immigrant groups, minority communities or ethnic groups interacts with economic exclusion from the market and political exclusion from democracy.

Clearly, there is an overlap between those excluded by market economy and those excluded by political democracy, just as there is an overlap between those included by market economy and those included by political democracy. The poor who are marginalized in the economy also do not have a voice in the polity, just as the rich who are dominant in the economy also have a strong political voice. Economic deprivation and political marginalization go hand-in-hand in much the same way as economic strength and political power go hand-in-hand. There are two underlying factors. For one, the economy and the polity are connected and interdependent. For another, there is no equality among economic agents or political citizens in terms of their economic or political freedom to choose. There is, in fact, a hierarchy of freedoms, with more for some and less for others, where there is a significant overlap in the economic and political sphere. These two propositions add to our understanding of the interaction between markets and democracy (Nayyar, 2003a).

It needs to be said that the liberal paradox is much deeper. On the one hand, markets exclude people without entitlements, assets or capabilities. It is in the logic of markets. Yet, markets would like to include as many people as possible. For, in the words of Adam Smith: "the division of labour is limited by the size of the market". On the other hand, democracy includes people by a constitutional right to vote. It is the foundation of democracy. Yet, political processes seek to exclude or to marginalize those without a voice. That is what the pursuit and exercise of 
political power is about. The irony of this paradoxical situation is striking. Indeed, this twist in the tale further highlights the dialectics of the interaction between market economy and political democracy.

This dialectical relationship between markets and democracy, as also the interaction between economic and politics, becomes more complex when globalized economies are juxtaposed with national polities. However, the essential tensions, asymmetries, overlaps and paradoxes remain similar. The dialectical relationship also remains. Even so, two questions arise. First, how does a market economy, which is more global than local, influence national politics differently? Second, how does political democracy influence a globalized market economy differently, when compared with a national market economy that is much less integrated with the outside world?

\section{GLOBAL ECONOMICS AND NATIONAL POLITICS}

Globalization has indeed reduced degrees of freedom for nation states in the economic sphere which is so essential for countries that are latecomers to development. Indeed, the space for, and autonomy to formulate policies in the pursuit of national development objectives is significantly diminished. This is so for two reasons: unfair rules of the game in the world economy and consequences of integration into international financial markets.

In a world of unequal partners, it is not surprising that the rules of the game are asymmetrical in terms of construct and inequitable in terms of outcome. The strong have the power to make the rules and the authority to implement the rules. In contrast, the weak can neither set nor invoke the rules (Nayyar, 2002). The problem, however, takes different forms.

First, there are different rules in different spheres. The rules of the game for the international trading system, being progressively set in the WTO, illustrate this with clarity. There are striking asymmetries. National boundaries should not matter for trade flows and capital flows but should be clearly demarcated for technology flows and labour flows. It follows that developing countries would provide access to their markets without a corresponding access to technology and would accept capital mobility without a corresponding provision for labour mobility. This implies more openness in some spheres but less openness in other spheres. The contrast between the free movement of capital and the unfree movement of labour across national boundaries lies at the heart of the inequality in the rules of the game.

Second, there are rules for some but not for others. The conditions imposed by the IMF and the World Bank provide the most obvious example. There are no rules for surplus countries, or even deficit countries, in the industrialized world, which do not borrow from the multilateral financial institutions. But the Bretton Woods twins set rules for borrowers in the developing world and in the transition economies. In effect, IMF programmes of stabilization and World Bank programmes 
of structural adjustment seek to harmonize policies and institutions across countries, which is in consonance with the needs of globalization.

Third, the agenda for new rules is partisan. There is an attempt on the part of industrialized countries to create new multilateral agreements in the WTO, in many spheres, which is partly responsible for the impasse in the Doha Round. The primary object of this exercise is to set rules for a deeper integration in the world economy. And the WTO is seen as the place to lodge these agreements essentially because it incorporates an enforcement mechanism which provides a legal right to retaliate. But this agenda is not in the interest of developing countries. Such unfair rules, if imposed, are bound to further erode the policy space so essential for national development.

The existing (and prospective) rules of the WTO regime allow few exceptions and provide little flexibility to countries that are latecomers to industrialization. In comparison, there was more room for manouevre in the erstwhile GATT, inter alia, because of special and differential treatment for developing countries. The new regime is much stricter in terms of the law and the implementation. The rules on trade in the new regime make the selective protection or strategic promotion of domestic firms vis-à-vis foreign competition much more difficult. The tight system for the protection of intellectual property rights could pre-empt or stifle the development of domestic technological capabilities. The possible multilateral agreement on investment, should it materialize, would almost certainly reduce the possibilities of strategic bargaining with transnational firms. Similarly, commitments on structural reform, an integral part of stabilization and adjustment programmes with the IMF and the World Bank, inevitably prescribe industrial deregulation, privatization, trade liberalization and financial deregulation. In sum, the new regime appears rule-based but the rules are not uniform. And it is not clear how or why this is better than discretion. For, taken together, such rules and conditions are bound to curb the use of industrial policy, technology policy, trade policy and financial policy as strategic forms of intervention to foster industrialization (Nayyar, 2002).

At the same time, the consequences of integration into international capital markets also reduce degrees of freedom. Exchange rates can no longer be used as a strategic device to provide an entry into world markets for manufactured goods, just as the interest rates can no longer be used as a strategic instrument for guiding the allocation of scarce investible resources in a market economy. What is more, countries that are integrated into the international financial system are constrained in using an autonomous management of demand to maintain levels of output and employment. Expansionary fiscal and monetary policies - large government deficits to stimulate aggregate demand or low interest rates to encourage domestic investment - can no longer be used because of an overwhelming fear that such measures could lead to speculative capital flight and a run on the national currency (Nayyar, 2007).

What is more, the gathering momentum of globalization, associated with an internationalization of financial markets, has led to the formulation of a rationale for orthodox macroeconomic policies that is almost prescriptive (Nayyar, 2011a). The objectives of price stability and fiscal balance have become sacrosanct, which 
defines the role of monetary policy and fiscal policy in the narrowest possible sense. Slowly but surely, this orthodoxy has also come to be embedded in the belief systems of individuals, who influence policy and shape opinion, in politics and in government. In this process, intellectuals from the world of academia provide the rationale and editors or columnists from the world of media provide the voice. It is no surprise that the orthodox belief system has been transformed into a virtual ideology. The ideology is not abstract. It is embedded in institutions, both international and national. For international financial markets, price stability is almost an article of faith, high interest rates ensure profitability and strong exchange rates impart confidence. Orthodox macroeconomic policies are simply a means to these ends. The same worldview is adopted by multilateral financial institutions, such as the IMF and the World Bank, which exercise enormous influence on policies of economies in crisis. It is only natural that this thinking is as much an integral part of national institutions even outside the world of finance. The advocacy may come from domestic financial sectors, but the policies are formulated by finance ministries while the practices are adopted by central banks.

In sum, the existing global rules encroach upon essential policy space. And the problem is compounded by the rapid, sometimes premature, integration into international financial markets. It is no surprise that these attributes of globalization also diminish space for democratic politics. This happens for at least three reasons.

First, global rules and financial markets in the outside world exercise significant influence on what governments can or cannot do in terms of fiscal policy, monetary policy, trade policy, industrial policy and exchange rate policy, in the pursuit of national objectives, so that economic decisions are not always shaped by the interests of their citizens. Second, the accountability, if not loyalty, of governments is divided and extends beyond national borders to multilateral rules, transnational corporations and international financial markets. Indeed, for economies that are vulnerable, even credit rating agencies become larger than life. Third, the accountability of governments to their people, who elect them or whom they represent, is eroded. In an ideal world, such accountability to citizens alone is a prior.

It is clear that markets and globalization reduce the economic policy space for nation states. There is also a reduction, not quite as much, in political space. Even so, there is some dilution of democratic politics in terms of objectives pursued by governments and their accountability to people. Is it possible that political democracy within nation states might provide checks and balances vis-à-vis markets and globalization? This a natural question that arises. Yet, it is seldom addressed.

\section{DIALECTICAL RELATIONSHIP WITH POLITICAL DEMOCRACY}

Economics provides a critical yet limited perspective on globalization, a multidimensional phenomenon, the consequences of which extend much beyond the economic to the political, social and cultural. And it would be no exaggeration to state that the whole is different from the sum total of its parts. Obviously, it would 
mean too much of a digression to discuss every dimension. Yet, it is essential to focus on some aspects of the political implications, to highlight the dialectical nature of the relationship between globalization and democracy.

Globalization has been associated with simultaneous, yet asymmetrical, consequences for countries and for people. There is an inclusion for some and an exclusion, or marginalization, for many. There is affluence for some and poverty for many. There are some winners and many losers. And there is an exclusion of people, as also countries, from the process. Beyond the economic, globalization has added a new dimension to the exclusion of people from development (Nayyar, 2003). Exclusion is no longer simply about the inability to satisfy basic human needs in terms of food, clothing, shelter, health care and education for large numbers of people. It is much more complicated. For the consumption patterns and lifestyles of the rich associated with globalization have powerful demonstration effects. People everywhere, even the poor and the excluded, are exposed to these consumption possibility frontiers because the electronic media has spread the consumerist message far and wide. This creates both expectations and aspirations. But the simple fact of life is that those who do not have the incomes cannot buy goods and services in the market. Thus, when the paradise of consumerism is unattainable, which is the case for common people, it only creates frustration or alienation. The reaction of people who experience such exclusion differs. Some seek short cuts to the consumerist paradise through drugs, crime or violence. Some seek refuge in ethnic identities, cultural chauvinism or religious fundamentalism. Such assertion of traditional or indigenous values is often the only thing that poor people can assert for it brings an identity and meaning to their lives. These outcomes have obvious political consequences.

It would seem that globalization has created two worlds that co-exist in space even if they are far apart in well-being (Nayyar, 2007). For some, in a world more inter-connected than ever before, globalization has opened door to many benefits. Open economies and open societies are conducive to innovation, entrepreneurship and wealth creation. For many, the fundamental problems of poverty, unemployment and inequality persist. Of course, these problems existed even earlier. But globalization may have accentuated exclusion and deprivation, for it has dislocated traditional livelihoods (World Commission on the Social Dimension of Globalization, 2004).

The people who reap the benefits and capture the opportunities are included. Some are winners. Economic prosperity does translate into political empowerment with voice and influence, creating political constituencies for markets and globalization. It is ironical that this process also creates a crisis of identity, particularly for the elite, who believe they have more in common with the global rich than their less privileged fellow citizens. The outcome might be a secession of the successful. But there are others, from an aspiring urban middle class that benefits from globalization, who not have such an identity crisis and are more empowered in the political process.

The people who bear the costs and face the risks are marginalized if not ex- 
cluded. Some are losers. The visible, yet unattainable, islands of prosperity provide a sharp contrast with the sea of deprivation in which they live. Their search for identities, whether social, ethnic or religious, is an inevitable consequence. And its assertion lends meaning to their lives. But it is also a means of acquiring a collective voice that is audible in the political process. The object is to combat exclusion through social resistance or political protest. In some countries, this is supported if not reinforced by organizations or even citizens from civil society.

Globalization is driven by market forces, whether the lure of profit or the threat of competition, and technical progress, which has dismantled geographical barriers of distance in terms of both time and costs. The synthesis of communications technology, which is concerned with the transmission of information, and computer technology, which is concerned with the processing of information, has created information technology, which is remarkable in both reach and speed. The consequences of this technological revolution are far reaching in every sphere. The most visible manifestation among people is mobile telephones. An exponential growth in the number of telephones has been combined with a phenomenal spread across the world, including poor countries and poor people. In itself, through connectivity alone, this revolution in communications has fostered economic, social and political empowerment. At the same time, access to Internet has expanded at a scorching pace, which has imparted social media software - Facebook, Twitter and the like - a fantastic reach. This has empowered the aspiring middle class in the political domain, everywhere, not only in articulating collective voice but also in mobilization through networking.

More information on economy and polity has created a milieu that is conducive to greater sensitivity about social realities. In such a context, easier and better methods of communication have enhanced awareness of rights and identities, just as they have enhanced awareness of widening disparities. Taken together, these developments have created a much greater rights consciousness among citizens. In countries where social and economic inequalities are high or rising, there is a juxtaposition of deprivation with aspiration. The widespread access through communications technology, just through mobile telephones with the rudimentary sms, has enabled social movements to mobilize opinion. This manifestation of the technological revolution, which is among the critical factors driving globalization, has some consequences for politics.

For one, it broadens and could strengthen political democracy everywhere. But it is particularly important in the developing world, where elections, even if free and fair, do not ensure freedoms and rights for citizens. The arena of politics is often preserved for established political parties or insiders by barriers to entry, whether money or kinship, that are formidable. And political mobilization is a difficult task for outsiders. This is so for political parties that are new entrants. It is even more difficult for individuals who are concerned or dissenting citizens. In such situations, access to information and ability to communicate empowers citizens in terms of voice, if not influence, to demand their freedoms and claim their rights. Social movements and social media together can reinforce this process through 
mobilization of opinion on issues of concern to citizens and society. It is plausible to argue that these processes might provide more effective checks and balances in what are sometimes choice-less democracies.

For another, it questions and could weaken authoritarian governments everywhere. It is plausible to argue that this is far more effective in challenging authoritarian regimes than popular movements of citizens were in the past. The process is much less visible and much less susceptible to control. It is able to reach out across geographical space and create coalitions of the willing. Thus, mobilization is far more effective. The speed at which dissent or opinion can be mobilized, against dictatorships, could not have been imaginable even a decade ago. The Arab Spring, or the Jasmine Revolution, provide a powerful example, as dictatorial regimes were ousted by people, although ultimate outcomes turned out to be different in Tunisia and Egypt, while similar processes were aborted by outside intervention in Libya or Bahrain. Even without regime change, such empowerment of citizens through information and communication creates space for political dissent by people. This is discernible in several countries across the world, such as China and Iran, where authoritarian governments allow little room for dissent on the part of citizens. The industrialized world is not quite an exception. In Europe, both Greece and Cyprus, people resisted elected governments on policies dictated by the IMF and the European Union in the wake of the financial crisis. Ultimately, in January 2015, this led to a political regime change in Greece, as its people decisively rejected the ruling political coalition of the conservative and social democratic parties (ND and PASOK), and elected SYRIZA, a left-wing party, with a near majority as it won 149 out of 300 seats in the Hellenic Parliament.

It is important to stress that the broadening or strengthening of political democracy and the questioning or weakening of authoritarian regime comes not only from the aspiring middle class, but also from those marginalized or deprived by markets and globalization. Both sets of citizens are empowered by information and communication technologies that have reached ordinary people. Of course, the significance of the aspiring middle classes is more audible and visible. But the poor or the deprived are no longer reconciled to a quiet acceptance of their fates, which was almost the norm earlier, as this new empowerment provides them with a voice to protest and to mobilize for seeking a better world.

The argument developed here suggests two hypotheses. These are intuitively plausible, even if difficult to prove, and highlight the dialectical nature of the relationship between globalization and democracy.

First, the broadening if not strengthening of political democracy, where such democracy already exists, attributable to technologies that provide citizens access to information and ability to communicate, helps reclaim some accountability of governments to their people that has been eroded or diminished by markets and globalization. Similarly, the questioning if not weakening of authoritarian regimes, where democracy does not exist, through the same technologies, also helps restore or create some accountability of governments to their people because, in a global- 
ized world where citizens are conscious of the reality in other countries, even authoritarian regimes are ultimately accountable if only to sustain themselves.

Second, the technologies associated with globalization that empower citizens through spread of information and means of communication, are conducive to political mobilization on issues when the consequences of markets and globalization cross thresholds of tolerance in countries where democracy exists in some form. In effect, then, such empowerment of people provides checks and balances that work through a democratic political process to impose curbs or introduce correctives. Similarly, in countries with authoritarian regimes, citizens empowered with much greater access to information and communication are able to articulate political voice on issues where they are hurt by outcomes that can be linked to markets and globalization. Once this voice is audible, such governments too might be more responsive to concerns of people. Even undemocratic regimes might intervene to correct the situation if some checks and balances kick-in.

The Latin American experience during the 2000s provides some validation of my hypothesis about the dialectical relationship between globalization and democracy. Most countries in this continent embraced markets and globalization starting around 1980. Some, such as Chile, did so with enthusiasm, while others such as Argentina or Brazil did so under duress driven by the IMF and the World Bank or by international financial markets. The outcome was the lost decade during the 1980s when growth was stifled and per capita income declined. This hurt people particularly the poor. The 1990s witnessed a slow recovery. But most economies in Latin America at the turn of the century were roughly where they had been two decades earlier. In the perception of people, these lost decades were attributed to the negative consequences of markets and globalization. In this context, access to information and means of communication, provided to people by technologies associated with globalization, did broaden and strengthen political democracy in countries where it existed, just as it did question and weaken authoritarian regimes in countries which were not democratic. The outcome was not just a resurrection of political democracy but the election of social democratic parties and left-ofcentre governments in several Latin American countries. And, during the 2000s, most of these governments, responsive to the concerns of people, sought to address problems poverty and inequality, through economic policies with a focus on social sectors (Cornia, 2014). These efforts led to progress in terms of human development, through educational opportunities which created capabilities and public health which improved the wellbeing of people, even if there was not enough employment creation.

\section{CONCLUSION}

In conclusion, I would like to emphasize that the relationship between globalization and democracy does not conform to ideological caricatures. It is neither linear nor unidirectional. In fact, the relationship between market economy and 
political democracy in a national context is mirrored in the relationship between globalization and democracy in the international context. These relationships are dialectical. The causation runs in both directions in different spheres. And there is an interaction between economics and politics that shapes outcomes. This essay, which has explored what globalization and democracy mean for each other, is no more than a modest beginning. There are some questions that need asking, just as there are other questions that need answers. It is time to reflect further on the consequences of globalization not only for economy but also for polity and society. It is also time to rethink how political change might occur within countries in the future as compared with the past.

\section{REFERENCES}

Bhaduri, Amit and Deepak Nayyar (1996). The Intelligent Person's Guide to Liberalization, New Delhi: Penguin Books.

Chang, Ha-Joon (2007). Bad Samaritans: Rich Nations, Poor Policies and the Threat to the Developing World, London: Random House.

Cornia, G. Andrea (2014). Falling Inequality in Latin America: Policy Changes and Lessons, Oxford: Oxford University Press.

Friedman, Thomas (1999). The Lexus and the Olive Tree, New York: Farrar, Straus and Giroux.

Nayyar, Deepak (2002). 'The Existing System and the Missing Institutions', in Deepak Nayyar ed. Governing Globalization: Issues and Institutions, Oxford: Oxford University Press.

Nayyar, Deepak (2003). 'Globalization and Development Strategies', in John Toye ed. Trade and Development, Cheltenham: Edward Elgar.

Nayyar, Deepak (2003a). 'The Political Economy of Exclusion and Inclusion: Democracy, Markets and People', in Amitava Krishna Dutt and Jaime Ros eds. Development Economics and Structuralist Macroeconomics: Essays in Honour of Lance Taylor, Cheltenham: Edward Elgar.

Nayyar, Deepak (2006). 'Globalization, History and Development: A Tale of Two Centuries', Cambridge Journal of Economics, Volume 30, Number 1, pp. 137-159.

Nayyar, Deepak (2007). 'Development through Globalization?', in George Mavrotas and Anthony Shorrocks eds. Advancing Development: Core Themes in Global Economics, London: Palgrave.

Nayyar, Deepak (2011). 'The Financial Crisis, the Great Recession and the Developing World', Global Policy, Volume 2, Number 1, pp. 20-32.

Nayyar, Deepak (2011a). 'Rethinking Macroeconomic Policies for Development', Brazilian Journal of Political Economy, Volume 31, Number 3, pp. 339-351.

Rodrik, Dani (2000). 'How Far Will International Economic Integration Go?, Journal of Economic Perspectives, Vol.14, No. 1, pp.177-186.

Rodrik, Dani (2011). The Globalization Paradox: Democracy and the Future of the World Economy, W.W.Norton, New York.

Taylor, Lance (2004). Reconstructing Macroeconomics, Cambridge, Massachusetts: Harvard University Press.

World Commission on the Social Dimension of Globalization (2004). A Fair Globalization: Creating Opportunities for All, Geneva: ILO. 